\title{
Hydrolysis of Insoluble Fish Protein Residue from Whitemouth croaker (Micropogonias furnieri) by Fungi
}

\author{
Vilásia Guimarães Martins ${ }^{1}$, Simone Canabarro Palezi ${ }^{1}$, Jorge Alberto Vieira Costa ${ }^{2}$ and \\ Carlos Prentice $^{1 *}$ \\ ${ }^{1}$ Laboratório de Tecnologia de Alimentos; Escola de Química e Alimentos; Universidade Federal do Rio Grande; \\ Rio Grande - RS - Brasil. ${ }^{2}$ Laboratório de Engenharia Bioquímica; Escola de Química e Alimentos; Universidade \\ Federal do Rio Grande; Rio Grande - RS - Brasil
}

\begin{abstract}
A significant amount of insoluble fibrous protein, in the form of feather, hair, scales, skin and others are available as co-products of agro industrial processing. These wastes are rich in keratin and collagen. This study evaluated different fungi for the hydrolysis of insoluble fish protein residues. Proteins resulting from Micropogonias furnieri wastes through $\mathrm{pH}$-shifting process were dried and milled for fermentation for $96 \mathrm{~h}$. This resulted the production of keratinolytic enzymes in the medium. Trichoderma $s p$. on alkaline substrate $\left(28.99 \mathrm{U} \mathrm{mL}^{-1}\right)$ and Penicillium $s p$. on

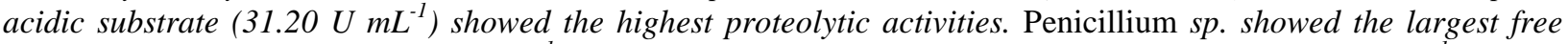
amino acid solubilization $\left(0.146 \mathrm{mg} \mathrm{mL}^{-1}\right)$ and Fusarium sp. the highest protein solubilization $\left(6.17 \mathrm{mg} \mathrm{mL}^{-1}\right)$.
\end{abstract}

Key words: fish waste, fungi, fibrous proteins, hydrolysis, Whitemouth croaker

\section{INTRODUCTION}

The exploitation of natural resources and increasing environmental pollution requires the need of a most valuable use of wastes generated from the processing plants and fish species of low commercial value. Generally, this material is converted into animal feed (Ferreira and Hultin 1994). The protein hydrolysis processes, either chemical, or enzymatic, generate insoluble proteins from the bones, skin and scales, which are not recovered and are often discharged to the environment (Guerard et al. 2002). However, the insoluble protein can be converted into useful biomass as proteins, or amino acids concentrated by microbial protease (Anwar and Saleemuddin 1998).
The fishing industry of Rio Grande (Brazil) processes a wide variety of species: however, only a portion is used as food for direct human consumption, the remaining constitutes a byproduct rich in proteins and lipids that can be transformed into various useful products, such as surimi, or protein hydrolysates (Lempek et al. 2007). Whitemouth croaker (Micropogonias furnieri) is a fish of low commercial value, highly caught by fishing ships in southern Brazil, and has been industrialized by the fishing industries of Rio Grande, creating a large amount of residue (Martins et al. 2011).

The use of agro industrial wastes provides value to the industry and increases energy conservation and recycling conscious (Aguiar et al. 2010). These facts have stimulated the studies to convert the waste keratin products to value-added products. Although the keratin hydrolysis by microbial

*Author for correspondence: dqmprent@ furg.br 
enzymes has been described previously (Noval and Nickersen 1959), studies on keratinase have been increasing. However, the mechanism of keratin biodegradation by microorganisms remains unclear (Kunert and Stransky 1988; Kunert 1992; Böckle and Müller, 1997; Brandelli 2008). These studies have been focused on proteolytic microorganisms.

Collagen is an insoluble fibrous protein that makes up the majority of bone tissue, skin, and connective tissues. It has a spatial structure, and high molecular weight and insoluble in water. Keratins are insoluble structural proteins of scales, feathers and are known for their high stability. The keratin chain is well packed into $\alpha$-helical, or $\beta$ helix in a polypeptide chain supercoiled (Kreplak et al. 2004), resulting in high mechanical stability and resistance to common proteolytic enzymes such as pepsin, trypsin, and papain (Jones et al. 1999).

Filamentous fungi synthesize a variety of hydrolytic enzymes. Many species are used in industrial process for the production of enzymes such as proteases, carbohydrases, and lipases. Friedrich et al. (1999) evaluated several fungal strains to identify active producers of keratinase for use in medical products and cosmestics, which included Penicillium, Aspergillus, Fusarium and Trichoderma. Keratinolytic enzymes are produced by fungi, bacteria and actinomycetes, which have been frequently isolated from the soils with keratin deposited materials (Santos et al. 1996; Kaul and Sumbali 1997). The strains of A. fumigatus and A. flavus producing keratinases have been described by Santos et al. (1996). Keratinases are included in a particular class of proteolytic enzymes that are able to degrade the keratinolytic substrates. The modification of the structure of keratin may be carried out by thermal, or enzymatic hydrolysis by reducing disulfide and peptide bonds (Williams et al. 1990, Kim et al. 2005). However, current processes for obtaining these residues are expensive and can destroy certain amino acids, yielding a product with a low digestibility and variable nutritional quality (Wang and Parsons 1997). Thus, the present study aimed to evaluate the proteolytic activity of ten fungal strains on insoluble substrates, resulting from a $\mathrm{pH}$-shifting process carried out from the wastes of Whitemouth croaker (Micropogonias furnieri).

\section{MATERIALS AND METHODS}

\section{Raw material}

Whitemouth croaker (Micropogonias furnieri) was obtained from fish processing companies at Rio Grande, Southern Brazil. The fish was transported in ice-filled containers to the laboratory washed immediately with chlorinated water, beheaded, eviscerated, and filleted. The waste such as viscera, bones, scales, skin and head, were placed in plastic containers and stored frozen at $-18^{\circ} \mathrm{C}$.

\section{Microorganisms}

Ten different fungal strains were used: four strains of Aspergillus sp. (E7, E17, E19 and O5), two of Fusarium sp. (E1 and E5), two of Penicillium sp. (E12 and E20) and two of Trichoderma sp. (E13 and E18) isolated by Laboratory of Fermentation of University of Passo Fundo, Brazil. The strains were maintained at $4^{\circ} \mathrm{C}$ on slant of potato-dextrose agar (PDA) medium with $1 \%(\mathrm{v} / \mathrm{v})$ additional agar-agar.

\section{Insoluble fish substrates}

Two kinds of insoluble residues were used as substrates, both resulting from the production of fish protein isolate through $\mathrm{pH}$ shifting process. First, two processes of chemical solubilization (acid and alkaline) were conducted to obtain the protein isolate from wastes such as viscera, bones, scales, skin and head. Samples were homogenized in a mechanical stirring at $150 \mathrm{rpm}$ for $5 \mathrm{~min}$ with distilled water (water:substrate, 5:1). The reaction was conducted in a closed reactor under stirring and controlled temperature. The alkalinizing agent was $1 \mathrm{~mol} \mathrm{~L}^{-1} \mathrm{NaOH}$ and the acidifying agent was $1 \mathrm{~mol} \mathrm{~L}^{-1} \mathrm{HCl}$. Acid solubilization was performed at $\mathrm{pH} 2.5$ and $30^{\circ} \mathrm{C}$ for $20 \mathrm{~min}$ and alkaline solubilization was carried out at $\mathrm{pH} 12.0$ and $20^{\circ} \mathrm{C}$ for $20 \mathrm{~min}$ (Martins et al. 2009). After solubilization, the substrate was centrifuged at $9000 \times g$ for 15 min. During centrifugation, the samples were separated in three phases. The upper phase (neutral lipids) and the middle phase (soluble proteins) were discarded and the bottom phase (insoluble proteins) was reserved for further processing. The insoluble proteins were dehydrated in a tray-dryer for $13 \mathrm{~h}$ at $50^{\circ} \mathrm{C}$. After that, it was ground in a knife-mill in order to standardize the particle size as $1 \mathrm{~mm}$; then, it was used in the fermentation. 


\section{Fermentative Process}

Spores were scraped from the slopes into $5.0 \mathrm{~mL}$ of $0.2 \%(\mathrm{v} / \mathrm{v})$ aqueous Tween 80 and $0.5 \mathrm{~mL}$ of the suspension transferred to each of two Roux flasks containing PDA and incubated at $30^{\circ} \mathrm{C}$ for five days. Spores were scraped off the PDA, suspended in $0.2 \%(\mathrm{v} / \mathrm{v})$ aqueous Tween 80 solution and enumerated using a Neubauer counting chamber (Martins et al. 2006). During the submerged fermentative process the strains were cultivated in a mineral salt medium $\left(0.5 \mathrm{~g} \mathrm{~L}^{-1}\right.$ $\mathrm{NaCl}, 0.4 \mathrm{~g} \mathrm{~L}^{-1} \mathrm{KH}_{2} \mathrm{PO}_{4}, 0.015 \mathrm{~g} \mathrm{~L}^{-1} \mathrm{CaCl}_{2} .2 \mathrm{H}_{2} \mathrm{O}$ ) and $2 \%$ substrate. The fermentation was carried out under aseptic conditions in $250 \mathrm{~mL}$ erlenmeyer flasks containing $100 \mathrm{~mL}$ of autoclaved medium and the initial $\mathrm{pH}$ was adjusted to 4.5 using $1 \times 10^{6}$ spores $\mathrm{mL}^{-1}$ as inoculum. The flasks were incubated at $30^{\circ} \mathrm{C}$ in an orbital shaker at $100 \mathrm{rpm}$ for $96 \mathrm{~h}$. Samples were withdrawn each $24 \mathrm{~h}$ for $\mathrm{pH}$ measurement.

\section{Proteolytic Activity}

The samples were centrifuged at $10,000 \times g$ for 5 min and enzyme activity was measured in the supernatant as described elsewhere (Thys et al. 2004), using azocasein as substrate. The enzyme solution $(120 \mu \mathrm{L})$ was added to $480 \mu \mathrm{L}$ of azocasein solution $\left(10 \mathrm{mg} \mathrm{mL}^{-1}\right)$ with $25 \mathrm{mmol} \mathrm{L}^{-1}$ tris $\mathrm{HCl}$ buffer $(\mathrm{pH} 8.0)$. The mixture was incubated at $45^{\circ} \mathrm{C}$ for $40 \mathrm{~min}$ and the reaction was stopped by adding $600 \mu \mathrm{L}$ of $10 \% \quad(\mathrm{w} / \mathrm{v})$ trichloroacetic acid (TCA) and keeping at $10{ }^{\circ} \mathrm{C}$ for $10 \mathrm{~min}$. The mixture was then centrifuged at $10,000 \times g$ for $5 \mathrm{~min}$ and $800 \mu \mathrm{L}$ of the supernatant was added to $200 \mu \mathrm{L}$ of $1.8 \mathrm{~mol} \mathrm{~L}^{-1}$ $\mathrm{NaOH}$. Absorbance at $420 \mathrm{~nm}$ was measured with a Biospectro Sp-22 spectrophotometer. A control was simultaneously run using distilled water. One unit of enzyme activity was defined as the amount of protein that resulted in an increase of absorbance at $420 \mathrm{~nm}$ of 0.01 under the assay conditions used.

\section{Free Amino Acid Concentration}

The free amino acid concentration was measured as described elsewhere (Moore 1968). Samples $(100 \mu \mathrm{L})$ were added to $2.0 \mathrm{~mL}$ of $0.1 \mathrm{~mol} \mathrm{~L}^{-1}$ phosphate buffer ( $\mathrm{pH}$ 7.2). Then $500 \mu \mathrm{L}$ of these samples were mixed with $500 \mu \mathrm{L}$ of $50 \mathrm{mg} \mathrm{mL}^{-1}$ ninhydrin. The mixture was incubated at $100^{\circ} \mathrm{C}$ for $15 \mathrm{~min}$, followed by an ice bath to reach room temperature. Then $5.0 \mathrm{~mL}$ of $50 \%(\mathrm{v} / \mathrm{v})$ ethanol was added to the tubes. The analysis was performed in triplicate and the absorbance at 560 $\mathrm{nm}$ was measured in a Biospectro SP-22 spectrophotometer. A control was simultaneously run using distilled water $(100 \mu \mathrm{L})$. The standard curve was developed with glycine.

\section{Soluble Protein}

The concentration of soluble protein was determined by the Folin phenol reagent method (Lowry et al. 1951) with bovine serum albumin (BSA) as a standard protein. The absorbance at $750 \mathrm{~nm}$ was measured in a Biospectro SP-22 spectrophotometer. A control was simultaneously run using distilled water $(200 \mu \mathrm{L})$.

\section{Statistical Analysis}

All the analyses were conducted in triplicates and at each $24 \mathrm{~h}$ along the fermentative process. The data were evaluated by the analysis of variance (ANOVA) using Tukey's test.

\section{RESULTS AND DISCUSSION}

\section{Changes in pH medium during the fermentation}

The initial $\mathrm{pH}$ of the fermentative medium was adjusted to 4.5. In some runs the $\mathrm{pH}$ remained constant around $\mathrm{pH} 4.0$ for $72 \mathrm{~h}$ and increased in the last $24 \mathrm{~h}$ : in some other cases a gradual increase occurred from the initial $\mathrm{pH} 4.5$ up to the final range between 7.0 and 8.0. Sangali and Brandelli (2000) also observed an increase in the $\mathrm{pH}$ values during the cultivation on raw feather degradation, indicating its strong keratinolytic character. Organisms with higher keratinolytic activity alkalinize the medium to a greater extent than those exhibiting lower keratinolytic activity (Kaul and Sumbali 1997). This tendency to alkalinize the medium results from the production of ammonia due to deamination of peptides and amino acids originating from keratin degradation. The resulting increase of $\mathrm{pH}$ is typical of microorganisms growing on protein substrates (De Toni et al. 2002; Riffel et al. 2003; Gradisar et al. 2005). The $\mathrm{pH}$ increase during the fermentative process is an important indiciation of the keratinolytic potential of microorganisms (Kim et al. 2001). During the keratin degradation, the thiol groups are also released. The thiol formation is accomplished by the reduction of disulfide bonds by both enzymatic (disulfide redutase) and 
chemical (sulfite and tiosulfate) mechanisms (Yamamura et al. 2002; Ramnani et al. 2005).

\section{Evaluation of soluble protein during fermentative process}

During the fermentative process the maximum substrates resulting from acid and alkaline hydrolysis was among 24, 48 and $72 \mathrm{~h}$. After reaching their maximum, both substrates indicated a decrease in the concentration. This behavior suggested that the microorganisms consumed part of the soluble protein that was available in the medium. In some cases, the concentration of soluble protein increased again after the reduction. The same behavior was observed by Riffel et al. (2003), who evaluated the soluble protein of feather keratin, when the maximum was reached at $24 \mathrm{~h}$ and a reduction occurred afterwards. In the alkaline substrate Fusarium E5 $\left(6.17 \mathrm{mg} \mathrm{mL}^{-1}\right)$ at $72 \mathrm{~h}$ and Aspergillus E7 $\left(5.72 \mathrm{mg} \mathrm{mL}^{-1}\right)$ at $96 \mathrm{~h}$ resulted highest protein. In the acidic substrate, the maximum attained was $0.987 \mathrm{mg} \mathrm{mL}^{-1}$ for the strain $\mathrm{O} 5$ at $96 \mathrm{~h}$. This was the only microorganism that obtained the maximum at this time; all the other strains reached the maximum in shorter times. Santos et al. (1996), working with $A$. fumigatus in a medium containing $1 \%$ of chicken feathers showed small amounts of soluble proteins with the maximum of $0.31 \mathrm{mg} \mathrm{mL}^{-1}$ at $\mathrm{pH} 7.2$.

Martins et al. (2011) evaluated the capacity of some bacteria with potential keratinolytic for the solubilization of the protein present in the residues of acidic and alkaline hydrolysis of fish wastes, which were studied in similar conditions to the present study. Bacillus velesensis gave the maximum yield with the alkaline substrate $(3.58$ $\mathrm{mg} \mathrm{mL}^{-1}$ ) at $24 \mathrm{~h}$ with $3 \%$ substrate concentration. In the acidic substrate, the maximum yield was $3.29 \mathrm{mg} \mathrm{mL}^{-1}$ at $48 \mathrm{~h}$ with the same bacterium and substrate concentration. The results showed the good efficiency of these strains when compared to other bacteria on the same substrates. The soluble protein concentration was higher than the free amino acids concentration in the majority of the steps of cultivation process. Aspergillus O5 attained the maximum protein solubilization in the acidic substrate and Fusarium E5 in the alkaline substrate.

\section{Solubilization of free amino acids}

Figure 1 shows the solubilization of amino acids during the fermentative process for each evaluated fungus in both the substrates. In the alkaline substrate, the amino acids release started from the beginning, but in the acidic substrate, an effective release started just from $24 \mathrm{~h}$ into fermentation.

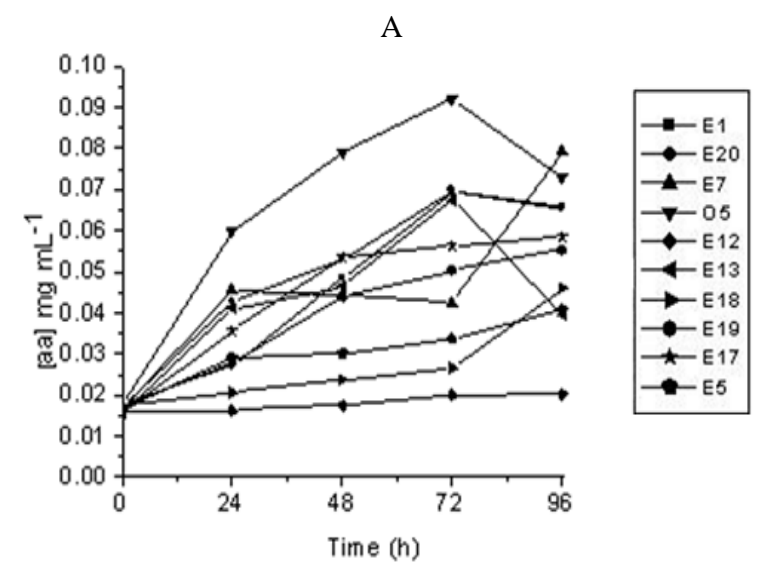

B

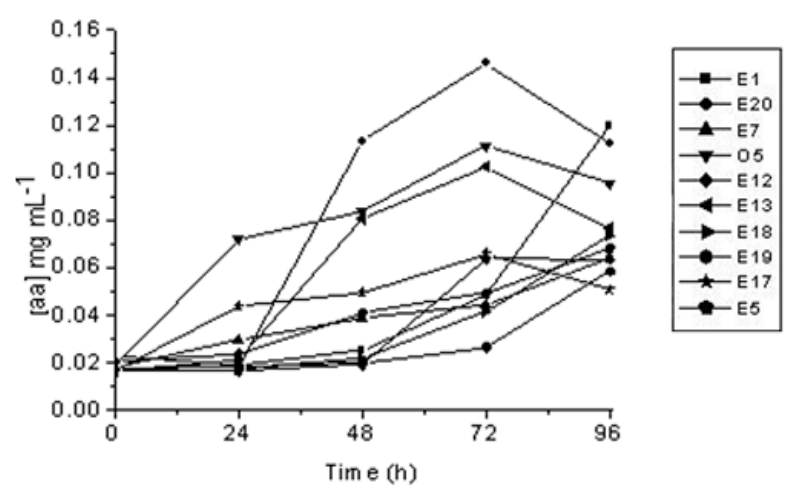

Figure 1 - Free amino acids concentration during the fermentative process (A) Alkaline substrate and (B) Acid substrate. E1 (Fusarium sp.), E20 (Penicillium sp.), E7 (Aspergillus sp.), O5 (Aspergillus sp.), E12 (Penicillium sp.), E13 (Trichoderma sp.), E18 (Trichoderma sp.), E19 (Aspergillus sp.), E17 (Aspergillus sp.) and E5 (Fusarium sp.).

In the alkaline substrate, the assay containing Aspergillus sp. O5 showed the highest soluble amino acids concentration $\left(0.092 \mathrm{mg} \mathrm{mL}^{-1}\right)$ among the evaluated fungi at $72 \mathrm{~h}$ of fermentation. The minimal concentration $\left(0.018 \mathrm{mg} \mathrm{mL}^{-1}\right)$ was obtained using Penicillium sp. E12 which remained the same during the whole process. Santos et al. (1996) evaluated A. fumigatus in a medium containing $1 \%$ of feather chicken at different $\mathrm{pH}$, which reached maximum soluble amino acids of $0.55 \mathrm{mg} \mathrm{mL}^{-1}$, which was higher than that obtained in this study. In the acidic substrate, a higher free amino acids concentration was reached when compared with the alkaline substrate. The maximum concentration was 
obtained using Fusarium sp. E20 (0.146 mg mL $\left.\mathrm{mL}^{-1}\right)$, followed by Aspergillus sp. O5 $\left(0.111 \mathrm{mg} \mathrm{mL}^{-1}\right)$, both at $72 \mathrm{~h}$. In the studies performed with bacteria on the same substrates as used in this study, similar results were obtained. The highest free amino acid concentration was obtained in the acidic substrate by $B$. velesensis $\left(0.178 \mathrm{mg} \mathrm{mL}^{-1}\right)$, followed by the $B$. cereus $\left(0.1146 \mathrm{mg} \mathrm{mL}^{-1}\right)$. In the alkaline substrate, the maximum was reached by Chryseobacterium sp. $\left(0.1263 \mathrm{mg} \mathrm{mL}^{-1}\right)$ (Martins et al. 2011). The statistical analysis carried out at $72 \mathrm{~h}$ for both the substrates showed that the solubilization of free amino acids was significant $(p<0.05)$ for all the strains with the exception of E1 and E5 for the acidic substrate and E1 and E20 for the alkaline substrate.

\section{Proteolytic activity determination}

Table 1 and 2 show the behavior of the microorganisms on both the substrates, all analyzes were performed in triplicate. It was observed that the highest proteolytic activity (31.20 $\mathrm{U} \mathrm{mL}^{-1}$ ) was reached using the acidic substrate by Penicilium sp. E20 at $72 \mathrm{~h}$ of the fermentative process. However, in general, the maximum activities were found in the alkaline substrate by Trichoderma sp. E13 (28.98 $\left.\mathrm{U} \mathrm{mL}^{-1}\right)$, Aspergillus sp. O5 (19.30 U mL $\left.\mathrm{L}^{-1}\right)$, Fusarium sp. E1 (16.34 $\left.\mathrm{U} \mathrm{mL}^{-1}\right)$ and Penicilium sp. E20 (14.73 $\left.\mathrm{U} \mathrm{mL}^{-1}\right)$. The other strains presented low proteolytic activity. In the acidic substrate, except strain E20, which reached the maximum activity $\left(31.20 \mathrm{U} \mathrm{mL}^{-1}\right)$ at $72 \mathrm{~h}$, the other two strains that presented highest activities were Fusarium sp. E1 and Aspergillus sp. O5, (5.36 and $5.90 \mathrm{U} \mathrm{mL}^{-1}$ respectively), although these activities were very low when compared with the E20. Notably, the strains that attained the maximum proteolytic activity in the acidic substrate were also the same that obtained the best results of enzyme production in the alkaline substrate.

Table 1 - Proteolytic activity in $\mathrm{U} \mathrm{mL}^{-1}$ during the fermentative process on alkaline substrate.

\begin{tabular}{cccccc}
\hline \multicolumn{5}{c}{ Alkaline Substrate } \\
\hline Fungi & $\mathbf{0}$ & $\mathbf{2 4 ~ h}$ & $\mathbf{4 8 ~ h}$ & $\mathbf{7 2 ~ h}$ & $\mathbf{9 6 ~ h}$ \\
\hline E1 & $1.91 \pm 0.015$ & $2.06 \pm 0.024$ & $6.41 \pm 0.027$ & $7.50 \pm 0.024$ & $16.34 \pm 0.188$ \\
E20 & $1.19 \pm 0.012$ & $7.30 \pm 0.040$ & $5.24 \pm 0.186$ & $5.77 \pm 0.210$ & $14.73 \pm 0.204$ \\
E7 & $0.90 \pm 0.020$ & $2.34 \pm 0.079$ & $2.43 \pm 0.054$ & $2.03 \pm 0.071$ & $3.17 \pm 0.053$ \\
O5 & $1.13 \pm 0.072$ & $6.06 \pm 0.095$ & $6.07 \pm 0.030$ & $5.31 \pm 0.016$ & $19.30 \pm 0.027$ \\
E12 & $0.22 \pm 0.016$ & $0.22 \pm 0.019$ & $1.70 \pm 0.048$ & $2.07 \pm 0.016$ & $2.26 \pm 0.022$ \\
E13 & $1.40 \pm 0.025$ & $4.68 \pm 0.160$ & $14.07 \pm 0.030$ & $28.99 \pm 0.041$ & $19.18 \pm 0.082$ \\
E18 & $0.27 \pm 0.006$ & $0.97 \pm 0.011$ & $1.67 \pm 0.024$ & $1.28 \pm 0.022$ & $1.68 \pm 0.015$ \\
E19 & $0.62 \pm 0.019$ & $1.80 \pm 0.029$ & $1.84 \pm 0.029$ & $2.61 \pm 0.029$ & $3.16 \pm 0.079$ \\
E17 & $0.52 \pm 0.020$ & $1.14 \pm 0.040$ & $1.41 \pm 0.108$ & $2.03 \pm 0.020$ & $2.40 \pm 0.050$ \\
E5 & $1.12 \pm 0.015$ & $1.29 \pm 0.034$ & $3.16 \pm 0.054$ & $3.84 \pm 0.016$ & $6.14 \pm 0.002$ \\
\hline
\end{tabular}

Table 2 - Proteolytic activity in $\mathrm{U} \mathrm{mL}^{-1}$ during the fermentative process on acid substrate.

\begin{tabular}{cccccc}
\hline \multicolumn{5}{c}{ Acid Substrate } \\
\hline Fungi & $\mathbf{0}$ & $\mathbf{2 4} \mathbf{h}$ & $\mathbf{4 8 ~ h}$ & $\mathbf{7 2 ~ h}$ & $\mathbf{9 6 ~ h}$ \\
\hline E1 & $0.80 \pm 0.036$ & $1.45 \pm 0.073$ & $2.40 \pm 0.014$ & $2.83 \pm 0.119$ & $5.64 \pm 0.087$ \\
E20 & $0.41 \pm 0.005$ & $0.74 \pm 0.027$ & $26.80 \pm 0.037$ & $31.20 \pm 0.056$ & $25.27 \pm 0.074$ \\
E7 & $0.72 \pm 0.041$ & $0.61 \pm 0.004$ & $0.74 \pm 0.025$ & $0.47 \pm 0.016$ & $1.24 \pm 0.016$ \\
O5 & $0.60 \pm 0.021$ & $3.04 \pm 0.039$ & $6.72 \pm 0.090$ & $4.68 \pm 0.005$ & $5.90 \pm 0.049$ \\
E12 & $0.51 \pm 0.047$ & $0.31 \pm 0.015$ & $0.41 \pm 0.016$ & $0.51 \pm 0.001$ & $0.55 \pm 0.006$ \\
E13 & $0.47 \pm 0.017$ & $1.15 \pm 0.037$ & $3.08 \pm 0.042$ & $5.06 \pm 0.108$ & $1.72 \pm 0.039$ \\
E18 & $0.36 \pm 0.012$ & $0.28 \pm 0.010$ & $0.91 \pm 0.068$ & $2.04 \pm 0.012$ & $3.76 \pm 0.046$ \\
E19 & $0.84 \pm 0.027$ & $0.70 \pm 0.012$ & $0.97 \pm 0.073$ & $2.06 \pm 0.055$ & $3.66 \pm 0.026$ \\
E17 & $0.74 \pm 0.025$ & $1.08 \pm 0.005$ & $1.72 \pm 0.015$ & $1.83 \pm 0.010$ & $2.05 \pm 0.008$ \\
E5 & $0.54 \pm 0.010$ & $0.70 \pm 0.012$ & $0.70 \pm 0.039$ & $1.06 \pm 0.062$ & $1.12 \pm 0.015$ \\
\hline
\end{tabular}

Most of the experiments showed the maximum proteolytic activity in $96 \mathrm{~h}$. This might have occurred due to the long adaptation phase of the fungi in the cultivation medium, considering that the medium of growth was not the same as fermentative medium. The statistical analysis performed at $96 \mathrm{~h}$ for the acidic and alkaline substrates showed that the proteolytic activity of the majority of strains in both the substrates presented statistical significance $(p<0.05)$. In acidic substrate, only between E5-E7 and E18E19, these were not significant $(p>0.05)$, and in alkaline substrate, between E7-E19, O5-E13 and E12-E17 also were not significant $(p>0.05)$. 
Martins et al. (2011) used the same substrates, but with bacteria and observed the maximum proteolytic activity in $48 \mathrm{~h}$, coinciding with the end of the exponential phase; then a decrease occurred and it increased again in $96 \mathrm{~h}$. Similar result was shown by Riffel et al. (2003) who worked with Chryseobacterium sp. $\mathrm{kr} 6$ in a medium containing $1 \%$ feather chicken at $\mathrm{pH} 8.0$ and $30^{\circ} \mathrm{C}$. The maximum activity was obtained in $48 \mathrm{~h}$. However, in both the cases, the microorganisms used were maintained in a medium similar to the fermentative medium. Martins et al. (2011) reported the maximum activity for the acid substrate with $B$. velesensis and for alkaline substrate by Chryseobacterium sp., which were 47.56 and $15.88 \mathrm{U} \mathrm{mL}^{-1}$, respectively. Jonsson and Martin (1965) evaluated different strains of fungi for proteases production and mentioned that the amount of proteases produced varied highly depending on the strain and the medium used. In order to obtain a higher production of commercial protease, it is essential to optimize the fermentative medium for better growth of the fungi and protease production.

The fungi used were able to produce enzymes to solubilize the proteins and amino acids from fibrous protein such as scales, bones, skin and cartilage from the acidic and alkaline hydrolysis performed with Withemouth croaker (Micropogonias furnieri) processing wastes. The proteins, peptides and amino acids resulting from these processes could be used to improve the efficiency of the hydrolysis process, increasing the amount of protein recuperated. They can be also used to raise the nutritional value of food stuffs. Penicillium sp. E20, Trichoderma sp. E13, Aspergillus sp. O5 and Fusarium sp. O1 were shown best producers of enzymes, consequently they were able to solubilize the highest amounts of protein and amino acids. Thus, it would be interesting to study other several fibrous substrates and these microorganisms, considering their keratinolytic and collagenolytic potential.

Although there is a wide range of studies discussing a great variety of uses of fish wastes, the use of microorganisms to hydrolyze insoluble protein from fish waste are rare. There are some works in this area but hydrolyzing chicken feather, nails and horn.

The most common use of the fish waste is to recover the components for animal feed, as silage fermentation, fish meal, and fish oil, etc. (Arvanitoyannis and Kassaveti 2008) as well as for the production of biodiesel/biogas (Lanari and Franci 1998); carotenoids extraction (Sachinda et al. 2006); enzymes extraction (Tavares et al. 1997); source of nitrogen for seaweed cultivation (Anderson et al. 1999); collagen isolate (Nagai and Suzuki 2000); protein hydrolysate (Bhaskar et al. 2008; Martins et al. 2009); chrome immobilization (Ozawa et al. 2003); lactic acid production (Gao et al. 2006); carbon sources (Damasio et al. 2011) and hydrolysis of collagen and keratin from bacterium (Martins et al. 2011) and fungi which were the goals of this study. The proteins, peptides, and amino acids recovered could be used to increase the yield in the traditional processes of fish based protein concentration.

\section{ACKNOWLEDGEMENTS}

The authors are grateful to CAPES and $\mathrm{CNPq}$ Brazil for providing the financial support and the Laboratory of Fermentation from University of Passo Fundo, Brazil that provided the fungal strains.

\section{REFERENCES}

Aguiar MM, Ferreira LFR, Monteiro RTR. Use of vinasse and sugarcane bagasse for the production of enzymes by lignocellulolytic fungi. Braz Arch Biol Technol. 2010; 53: $1245-1254$.

Anderson RJ, Smit AJ, Levitt GJ. Upwelling and fishfactory waste as nitrogen sources for suspended cultivation of Gracilaria gracilis in Saldanha Bay, South Africa. Hydrobiologia. 1999; 398/399: 455-462.

Anwar A, Saleemuddin M. Alkaline proteases: a review. Bioresour Technol. 1998; 64: 175-183.

Arvanitoyannis IS, Kassaveti A. Fish industry waste: treatments, environmental impacts, current and potential uses. Int J Food Sci Tech. 2008; 43: 726-745.

Bhaskar N, Benila T, Radha C, Lalitha RG. Optimization of enzymatic hydrolysis of visceral waste proteins of Catla (Catla catla) for preparing protein hydrolysate using a commercial protease. Bioresour Technol. 2008; 99: 335-343.

Böckle B, Müller R. Reduction of disulfide bonds by Streptomyces pactum during growth on chicken feathers. Appl Environ Microbiol. 1997; 63: 790-792.

Brandelli A. Bacterial keratinases: useful enzymes for bioprocessing agroindustrial wastes and beyond. Food Bioprocess Technol. 2008; 1: 105-116.

Damasio ARL, Maller A, Silva TM, Jorge JA, Terenzi HF, Polizeli MLTM. Biotechnological potential of alternative carbon sources for production of pectinases by Rhizopus microsporus var. Rhizopodiformis. Braz Arch Biol Technol. 2011; 54(1): 141-148. 
De Toni CH, Richter MF, Chagas JR, Henriques JAP, Termignoni C. Purification and characterization of an alkaline serine endopeptidase from a feather-degrading Xanthomonas maltophila strain. Can J Microbiol. 2002; 48: 342-348.

Ferreira NG, Hultin HO. Liquefying cod fish frames under acidic conditions with a fungal enzyme. $J$ Food Process Preserv. 1994; 18: 87-101.

Friedrich J, Gradisar H, Mandin D, Chaumont JP. Screening fungi for synthesis of keratinolytic enzymes. Lett Appl Microbiol. 1999; 28: 127-130.

Gao MT, Hirata M, Toorisaka E, Hano T. Acid-hydrolysis of fish wastes for lactic acid fermentation. Bioresour Technol. 2006; 97: 2414-2420.

Guerard F, Guimas L, Binet A. Production of tuna waste hydrolysates by a commercial neutral protease preparation. J Molec Catal B Enzym. 2002; 20: 489-498.

Gradisar H, Friedrich J, Krizaj I, Jerala R. Similarities and specificities of fungal keratinolytic proteases: Comparison of keratinases of Paecilomyces marquandii and Doratomyces microsporus to some known protease. Appl Environm Microbiol. 2005; 71: 3420-3426.

Jones LN, Simon M, Watts NR, Booy FP, Steven AC, Parry DAD. Intermediate filament structure: hard $\alpha$ keratin. Biophys Chem. 1999; 68: 83-93.

Jonsson AG, Martin SM. Protease production by Aspergillus fumigatus. Agr Biol Chem. 1965; 28: 734738.

Kaul S, Sumbali G. Keratinolysis by poultry farm soil fungi. Mycopathologia. 1997; 139: 137-140.

Kreplak L, Doucet J, Dumas P, Briki F. New aspects of the $\alpha$-helix to $\beta$-sheet transition in stretched hard $\alpha$-keratin fibers. Biophys J. 2004; 87: 640-647.

Kim JM, Choi YM, Suh HJ. Preparation of feather digests as fertilizer with $B$. pmnilus KHS-1. J. Microbiol Biotechnol. 2005; 15: 472-476.

Kim JM, Lim WJ, Suh HJ. Feather-degrading Bacillus species from poultry waste. Process Biochem. 2001; 37: 287-291.

Kunert J. Effect of reducing agents on proteolytic and keratinolytic activity of enzymes of Microsporum gypseum. Mycoses. 1992; 35: 343-348.

Kunert J, Stransky Z. Thiosulfate production from cysteine by the prokaryote Streptomyces fradide. Arch Microbiol. 1988; 150: 600-601.

Lanari D, Franci C. Biogas production from solid wastes removed from fish farm effluents. Aquat Living Resour. 1998; 11: 289-295.

Lempek TS, Martins VG, Prentice CH. Rheology of surimi-based products from fatty fish underutilized by the industry: argentine croaker (Umbrina canosai). $J$ Aquat Food Prod Technol. 2007; 16: 27-44.

Lowry OH, Rosebrough NJ, Farr AL. Protein measurement with the Folin phenol reagent. J Biol Chem. 1951; 193: 265-275.

Martins VG, Costa JAV, Prentice-Hernández C. Hidrolisado proteico de pescado obtido por vias química e enzimática a partir de corvina (Micropogonias furnieri). Quim Nova. 2009; 32: 61-66.
Martins VG, Costa JAV, Silveira ST, Brandelli A, Prentice $\mathrm{CH}$. Protein and amino acid solubilization using Bacillus cereus, Bacillus velesensis, and Chryseobacterium sp. from chemical extraction protein residue. Food Bioprocess Technol. 2011; 4: 116-123.

Martins VG, Kalil SJ, Bertolin TE, Costa JAV. Solid State Biosurfactant Production in a Fixed-bed Column Bioreactor. Z Naturforsch C:Biosci. 2006; 61c: 721-726.

Moore S. Amino acid analysis: aqueous DMSO as solvent for the ninhydrin reaction. J Biol Chem. 1968; 243: 6281-6283.

Nagai T, Suzuki N. Isolation of collagen from fish waste material - skin, bone and fin. Food Chem. 2000; 68: 277-281.

Noval JJ, Nickerson WJ. Decomposition of native keratin by Streptomyces fradiae. J Bacteriol. 1959; 77: 251-263.

Ozawa M, Satake K, Suzuki R. Removal of aqueous chromium by fish bone waste originated hydroxyapatite. J Mater Sci Lett. 2003; 22: 513-514.

Ramnani P, Singh R, Gupta R. Keratinolytic potential of Bacillus licheniformis RG1 structural and biochemical mechanism of feather degradation. Can J Microbiol. 2005; 51: 191-196.

Riffel A, Lucas F, Heeb P, Brandelli A. Characterization of a new keratinolytic bacterium that completely degrades native feather keratin. Arch Microbiol. 2003; 179: 258-265.

Sachindra NM, Bhaskar N, Mahendrakar NS. Recovery of carotenoids from shrimp waste in organic solvents. Waste Manage. 2006; 26: 1092-1098.

Sangali S, Brandelli A. Feather keratin hydrolysis by a Vibrio sp. Strain kr2. J Appl Microbiol. 2000; 89: 735743.

Santos RMD, Finnino AAP, Sá CM, Felix CR. Keratinolytic activity of Aspergillus fumigatus Fresenius. Curr Microbiol. 1996; 33: 364-370.

Tavares JFP, Baptista JAB, Marcone MF. Milkcoagulating enzymes of tuna fish waste as a rennet substitute. Int $J$ Food Sci Nutr. 1997; 48: 169-176.

Thys RCS, Lucas FS, Riffel A, Heeb P, Brandelli A. Characterization of a protease of a feather degrading Microbacterium species. Lett Appl Microbiol. 2004; 39: 181-186.

Wang X, Parsons CM. Effect of processing systems on protein quality of feather meals and hog hair meals. Poultry Sci. 1997; 76: 491-496.

Williams CM, Richter CS, Mackenzie JM, Shih JCH. Isolation, identification and characterization of a featherdegrading bacterium. Appl Environm Microbiol. 1990; 56: $1509-1515$.

Yamamura S, Morita Y, Hasan Q, Yokoyama K, Tamiya E. Keratin degradation: a cooperative action of two enzymes from Stenotrophomonas sp. Biochem Biophys Res Commun. 2002; 294: 1138-1143.

Received: April 03, 2013; Accepted: August 29, 2013. 